\title{
COVID-19 Case Likely Caused by Contaminated Object During Hotel Disinfection - Guangxi Zhuang Autonomous Region, China, January 2021
}

\author{
Jiatong Zhuo ${ }^{1, *}$
}

On January 13, 2021 in Nanning City of Guangxi Zhuang Autonomous Region, an individual (Patient A) tested positive for coronavirus disease 2019 (COVID-19). Patient A provided a disinfection service for a business hotel in Nanning that was designated by the government to accept international travelers entering China and quarantine the travelers for 14 days. Patient A had no history of travel and had previously tested negative for COVID-19 twice on January 4 and January 11, 2021.

From December 29, 2020 to January 13, 2021, Patient A mostly traveled by electronic scooter and wore personal protective equipment (PPE) diligently. Since there have been no domestic cases reported in Nanning recently, he was not likely to be infected through person-to-person aerosol transmission. $\mathrm{He}$ performed his disinfection work 9 times during the roughly 15-day period in the business hotel and was likely infected through a person-to-material route by a traveler returning from Indonesia. The traveler had stayed at the business hotel for a 14-day period, had tested negative twice, and was released on January 13 to return home to Shanxi. However, on January 20, the traveler tested positive for COVID-19 nucleic acids as well as IgM and IgG antibodies; he was subsequently diagnosed as an asymptomatic carrier of COVID-19.

Based on this finding, we believed Patient A's PPE was contaminated with COVID-19 during his management of the disinfection service. In addition, Nanning also had abnormally cold weather during this period as the city remained under $10{ }^{\circ} \mathrm{C}$ from December 29, 2020 to January 13, 2021, which likely helped keep the virus active. This evidence suggests that Patient A's PPE were likely contaminated during his disinfection activities in the hotel, and he likely became infected after using his hands to touch his PPE and then touching his mouth, nose, or eyes.

This material-to-person route of transmission has been reported in previous incidents including outbreaks stemming from a dockworker in Qingdao (1), a cargo worker at Shanghai's Pudong Airport (2), and the Xinfadi Wholesale Market in Beijing (3). This suggests that current disinfection protocols (4) should be improved so that workers are more vigilant while removing their PPE and will adhere more closely to post-disinfection protocols, including washing hands and not touching contaminated surfaces and objects.

doi: $10.46234 / \mathrm{ccdcw} 2021.046$

\# Corresponding author: Jiatong Zhuo, zjta28@163.com.

\footnotetext{
${ }^{1}$ Guangxi Center for Disease Control and Prevention, Nanning, Guangxi Zhuang Autonomous Region, China.
}

Submitted: February 04, 2021; Accepted: February 06, 2021

\section{REFERENCES}

1. Yuan Q, Kou ZQ, Jiang FC, Li ZJ, Zhang LJ, Liu HH, et al. A nosocomial COVID-19 outbreak initiated by an infected dockworker at Qingdao City Port - Shandong Province, China, October, 2020. China CDC Wkly 2020;2(43):838 - 40. http://dx.doi.org/10.46234/ccdcw 2020.224.

2. Fang FH, Song Y, Hao LP, Nie K, Sun XD. A case of COVID-19 detected in a cargo worker at Pudong airport - Shanghai Municipality, China, November 8, 2020. China CDC Wkly 2020;2(47):910 - 1 . http://dx.doi.org/10.46234/ccdcw2020.246.

3. Tan WJ, Niu PH, Zhao X, Pan Y, Zhang Y, Chen LJ, et al. Reemergent cases of COVID-19 - Xinfadi wholesales market, Beijing Municipality, China, June 11, 2020. China CDC Wkly 2020;2(27):502 - 4 . http://dx.doi.org/10.46234/ccdcw2020.132.

4. Wang JQ, Zhang BY, Duan HY, Liang C, Sun HH, Zhang J, et al. Key points of the program for disinfection technology in special places during the Coronavirus Disease-2019 (COVID-19) outbreak. China CDC Wkly 2020;2(9):140 - 2. http://dx.doi.org/10.46234/ccdcw2020.038. 